\title{
4
}

\section{LA DEFINICIÓN LOCAL DE LA PROBLEMÁTICA SOCIAL. LA CONFORMACIÓN DE LA AGENDA DE GOBIERNO EN UN MUNICIPIO DE LA PROVINCIA DE BUENOS AIRES}

\author{
Matías José lucci (•) \\ (CONICET/UNLP)
}

\section{RESUMEN}

Este trabajo tiene como objetivo analizar la conformación de la agenda de la política social en el nivel municipal de gestión. Se toma como caso el ingreso del Plan Municipal de Fortalecimiento a Programas Sociales a la agenda del gobierno electo en 2003 en un Municipio de la Provincia de Buenos Aires. El caso nos ofrece la oportunidad por indagar sobre dos problemas centrales referidos a la agenda de gobierno: la primera, sobre las condiciones bajo las cuales se establecen cambios en la agenda municipal con relación a las anteriores. La segunda cuestión, estrechamente vinculada a la primera, refiere al modo en que los agentes municipales identifican problemas sociales y proponen estrategias de intervención sobre los mismos. Una de las conclusiones más importante a la que se llega es que la definición de problemas públicos desde una perspectiva local encierra una dinámica en la que los agentes que intervienen en el campo de la política y administración en el nivel municipal plantean temas y problemas que pueden ser abordados a través de lineamientos y financiamientos que llegan desde los ámbitos nacionales y/o provinciales de gestión.

\section{PALABRAS CLAVES:}

agenda de gobierno, municipios, política social

\footnotetext{
(•)E-mail:matiasiu@yahoo.com.ar
}

\section{ABSTRACT}

The target of this work is surveying the making of a social policy agenda at municipality level. The case taken here is the inclusion of a municipal plan for the strengthening of social problems in a municipality of the province of Buenos Aires. The case offers us the opportunity for investigating on two central problems referred to the agenda of government: the first one, on the conditions under which changes are established in the local agenda by relation to the previous ones. The second question linked to the first one, recounts to the way in which the municipal agents identify social problems and propose strategies of intervention on the same ones. One of the conclusions more importantly of this paper is that the definition of public problems from a local perspective presents a dynamics in which the agents who intervene in the field of the policy and administration in the municipal level raise topics and problems that can be approached across limits and financings that come from the national and / or provincial areas of management.

\section{KEY WORDS:}

agenda setting, municipality, social policies

RECEPCIÓN DEL ARTÍCUL0: 04/05/09

ACEPTACIÓN FINAL: 06/11/09 